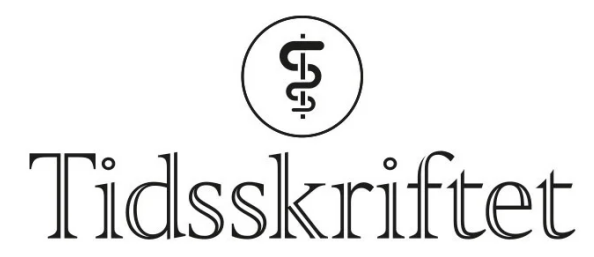

DEN NORSKE LEGEFORENING

\title{
Kan et portforbud ved covid-19 begrunnes medisinskfaglig?
}

DEBATT

\section{LINDA MADSEN}

linda.madsen@usn.no

Linda Madsen er førsteamanuensis i samfunnsvitenskap ved Senter for omsorgsforskning sør og Institutt for sykepleie- og helsevitenskap ved Universitetet i Sørøst-Norge. Hun har lang erfaring med forskning på smittevern, biosikkerhet, samfunnssikkerhet og krisehåndtering. Forfatteren har fylt ut ICMJE-skjemaet og oppgir ingen interessekonflikter.

\section{Det er på høy tid å se på hvordan medisinsk kunnskap blir brukt for å endre det juridiske grunnlaget for politiske intervensjoner.}

Regjeringen ønsker å styrke sin verktøykasse ved å lovhjemle portforbud hvis smittesituasjonen skulle eskalere. Nylig var et slikt lovforslag ute til høring (1). Justisminister Monica Mæland ønsker å kunne «handle raskt hvis nødvendig» (므), men på hvilken måte vil et portforbud kunne være et egnet "verktøy»? Vil det tilføre noe annet enn en falsk trygghet? Myndighetene klamrer seg til troen på at et portforbud er en siste utvei til tross for klare advarsler fra både Folkehelseinstituttet og Helsedirektoratet om at det neppe vil gi noen smittevernmessig "gevinst» $(3,4)$. Smittevernloven $\S 1-5$ sier at smitteverntiltak «skal være basert på en klar medisinskfaglig begrunnelse, være nødvendig av hensyn til smittevernet og fremstå tjenlig etter en helhetsvurdering.» Så, hvordan begrunner regjeringen behovet for portforbud medisinskfaglig?

\section{Utilstrekkelighet ved tiltak}

Det er i en eventuell situasjon med sterk smitteøkning at myndighetene ønsker å ha dette «verktøyet» for hånden. Flere høringsinnspill etterlyser klare kriterier for når myndighetene anser det som aktuelt å benytte portforbud. I Justis- og beredskapsdepartementet og Helse- og omsorgsdepartementets felles høringsnotat nevnes ulike indikatorer, som smittesituasjon, test-, smitteoppsporings- og behandlingskapasitet, tilgjengelighet av smittevernutstyr samt «risikoen ved ikke å innføre nye eller forsterkede tiltak» (1). I Tyskland har nasjonale myndigheter fastsatt en grense på antall smittede per 100 ooo innbyggere og et prosentvist belegg på intensivstasjoner som veiledende for å innføre regionale eller lokale portforbud (Ausgangssperre) (5). Problemet er at slike kriterier kun sier noe om smittesituasjonen - de sier ikke noe verken om positive mereffekter eller 
negative bieffekter av et portforbud. Slike smitte- og beleggstall fremstår (til tross for kjente svakheter) som klare indikasjoner på at smitteverntiltakene så langt har vært «utilstrekkelige».

\section{«Det er altså utilstrekkeligheten ved andre tiltak - og ikke portforbudets egnethet - som legges til grunn for å ta i bruk portforbud»}

Og det er nettopp utilstrekkeligheten ved andre tiltak som er den tilsynelatende selvsagte begrunnelsen også norske myndigheter bruker til å argumentere for portforbud. Det er altså utilstrekkeligheten ved andre tiltak - og ikke portforbudets egnethet - som legges til grunn for å ta i bruk portforbud. Ved å finlese departementenes høringsnotat og studere andre offentlige dokumenter samt helsemyndighetenes ordbruk i offentlig debatt, forblir det imidlertid uklart på hvilken måte et portforbud anses å være egnet til å bekjempe covid19.

\section{Inngripende tiltak må gi mereffekt}

Det argumenteres stadig for at portforbud har vist seg effektivt for å redusere smittetallene i de landene der det er brukt. En gjennomgang av internasjonal litteratur som taler for portforbudliknende tiltak, viser imidlertid at dette er kvantitative studier som gir leserne liten innsikt i hva begrepene curfew, stay at home orders, strict lock down og home isolation innebærer i praksis (6-9.). Like begrep kan ha svært ulikt innhold, for eksempel ser home isolation, slik det er brukt i en av artiklene (ㅁ), ut til å sammenfalle med en form for generelt portforbud. Dette kan neppe sammenliknes med hjemmeisolering slik det benyttes i en norsk kontekst, hvor det assosieres med personer som har testet positivt og skal isolere seg hjemme.

I tillegg er det slik at der man har gjort evalueringer av konkret portforbud hvor allmennheten forbys å ferdes i offentlige rom innen gitte tider eller hele døgnet, er portforbud alltid kombinert med innskjerping av andre smitteverntiltak. Det er derfor umulig å si noe om hvorvidt en eventuell stagnasjon eller nedgang i smitte er et resultat av portforbudet eller øvrige tiltak. I den nevnte litteraturen foreligger også liten eller ingen informasjon om kontekstuelle forhold av betydning for smittespredning og smittevern, slik som for eksempel demografi, geografi, sosiokulturelle og samfunnsøkonomiske forhold eller lokale variasjoner innad i land. Dette gjelder også for de landene som norske myndigheter, ved hjelp av sine ambassader, har innhentet informasjon fra (1).

\section{«Legeforeningen bestrider at portforbud er et egnet tiltak»}

Hvilke «medisinskfaglige», eller for den saks skyld «smittevernfaglige», begrunnelser får portforbud til å «fremstå tjenlig» som supplement til allerede tilgjengelige tiltak «etter en helhetsvurdering» (jf. smittevernloven)?

Et portforbud som tiltak for pandemikontroll blir av myndighetene begrunnet i medisinsk kunnskap om at virus overføres mellom menneskelige verter ved nærhet i tid og rom. Et portforbud føyer seg i så måte inn i den tilsynelatende uendelige rekken av smitteverntiltak som den norske smittevernloven gir rom for, og som har til hensikt å hindre smittespredning ved å sikre avstand mellom potensielle smittebærere og nye verter - inntil sistnevnte gruppe har blitt immunisert gjennom vaksinering. I sitt høringssvar påpeker imidlertid Legeforeningen «at det primært er samvær med andre personer som legger til rette for smitte, ikke det faktum alene at man beveger seg ut fra sitt eget hjem» (므). Legeforeningen bestrider at portforbud er et egnet tiltak. Liknende er påpekt også av andre høringsinstanser, som Det juridiske fakultet ved UiT, Fredrikstad kommune, Oslo kommune, Rettspolitisk forening, Universitetet i Sørøst-Norge mfl. (1). 
Medisinskfaglige råd som eventuelt skal tale for bruk av portforbud må snakke om mereffekten av dette tiltaket i forhold til mindre inngripende tiltak - og veie disse opp mot negative bieffekter. Høye smittetall, og det at andre tiltak anses å være utilstrekkelige, bygger på medisinskfaglig kunnskap, men kunnskapen om smittesituasjon gir verken faglig, empirisk eller vitenskapelig belegg som kan begrunne innføring av portforbud.

I sin høringsuttalelse vektlegger Legeforeningen at både innføringen av en hjemmel om portforbud og iverksetting av portforbud vil kunne svekke befolkningens tillit, «en skjør verdi som må forvaltes klokt» (므). På samme måte må myndighetene utvise klokhet og forstand i sin omgang med medisinskfaglig kunnskap når de skal velge og tilrettelegge for egnede smitteverntiltak.

\section{LITTERATUR}

1. Justis- og beredskapsdepartementet. Høring - forslag om endringer i smittevernloven (portforbud). Høringsnotat 8.1.2021. https://www.regjeringen.no/no/dokumenter/horing-forslag-omendringer-i-smittevernloven-portforbud/id2827769/ Lest 16.2.2021.

2. Regjeringen. Koronasituasjonen: Pressekonferanse med Mæland, Høie og Nybø onsdag 6. januar. Siterte ord er 3 min og 6 sekunder ute i sendingen.

https://www.regjeringen.no/no/aktuelt/koronasituasjonen-pressekonferanse-med-maland-hoie-ognybo-onsdag-6.-januar/id2826870/ Lest 16.2.2021.

3. Folkehelseinstituttet. COVID-19: Oppdrag fra HOD nr. 256 Overordnet Smittevernfaglig vurdering av strenge tiltak. 10.12.2020. https://www.helsedirektoratet.no/tema/beredskap-og-

krisehandtering/koronavirus/faglig-grunnlag-til-helse-og-omsorgsdepartementet-covid-19/FHI\%20\%20Oppdrag\%20256\%20-

\%20Overordnet\%2osmittevernfaglig\%2ovurdering\%2oav\%2ostrenge\%2otiltak.pdf/_/attachment/inline /72f78319-fg1a-4ddo-9d21-1f46f3d8e453:8647c72aee3487a201cc793fao261dbb86ab58ao/FHI\%2O-

\%20Oppdrag\%20256\%20-

\%20Overordnet\%2osmittevernfaglig\%2ovurdering\%2oav\%2ostrenge\%2otiltak.pdf Lest 16.2.2021.

4. Helsedirektoratet. Svar på covid-19 oppdrag fra HOD 256 - Overordnet smittevernfaglig vurdering av strenge tiltak. 11.12.2021. https://www.helsedirektoratet.no/tema/beredskap-og-

krisehandtering/koronavirus/faglig-grunnlag-til-helse-og-omsorgsdepartementet-covid-

19/Oppdrag\%20256\%20-

\%2oOverordnet\%2osmittevernfaglig\%2ovurdering\%2oav\%2ostrenge\%2otiltak.pdf/_/attachment/inline /9ec74b29-5337-4443-b68b-

d438do49c8dd:419b7oc2e22c02c430a8co6edb2989f15ccda863/Oppdrag\%20256\%20-

\%2oOverordnet\%2osmittevernfaglig\%2ovurdering\%2oav\%2ostrenge\%2otiltak.pdf Lest 16.2.2021.

5. Baden-Württembergs delstatsregjering. Begründung zur 3. Änderungsverordnung vom 8. Januar 2021 zur 5. Verordnung der Landesregierung über infektionsschützende Maßnahmen gegen die Ausbreitung des Virus SARS-CoV-2 (Corona-Verordnung - CoronaVO) vom 3o. November 2020. https://www.baden-

wuerttemberg.de/fileadmin/redaktion/dateien/PDF/Coronainfos/210110_Begruendung_zur_3.Aender ungsVO_zur_5.CoronaVO.pdf Lest 16.2.2021.

6. Alfano V, Ercolano S. The Efficacy of Lockdown Against COVID-19: A Cross-Country Panel Analysis. Appl Health Econ Health Policy 2020; 18: 509-17. [PubMed][CrossRef]

7. Flaxman S, Mishra S, Gandy A et al. Estimating the effects of non-pharmaceutical interventions on COVID-19 in Europe. Nature 2020; 584: 257-61. [PubMed][CrossRef]

8. Hsiang S, Allen D, Annan-Phan S et al. The effect of large-scale anti-contagion policies on the COVID-19 pandemic. Nature 2020; 584: 262-7. [PubMed][CrossRef]

9. Kharroubi S, Saleh F. Are Lockdown Measures Effective Against COVID-19? Front Public Health 2020; 8: 549692. [PubMed][CrossRef]

10. Den norske legeforening. Høringssvar - forslag om endringer i smittevernloven (portforbud). https://www.regjeringen.no/no/dokumenter/horing-forslag-om-endringer-i-smittevernlovenportforbud/id2827769/?uid=do6d1891-c58f-4cd9-agbb-7aae21377a2o Lest 16.2.2021.

Publisert: 22. februar 2021. Tidsskr Nor Legeforen. DOI: 10.4045/tidsskr.21.0105

C Tidsskrift for Den norske legeforening 2023. Lastet ned fra tidsskriftet.no 26. april 2023. 